\title{
Performance of Direct Carbon Fuel Cells Operated on Coal and Effect of Operation Mode
}

\author{
Andrew C. Chien, ${ }^{a}$ Ana Arenillas, ${ }^{b}$ Cairong Jiang, ${ }^{a}$ and John T. S. Irvine ${ }^{a, *, z}$ \\ ${ }^{a}$ School of Chemistry, University of St-Andrews, Fife KY16 9ST, United Kingdom \\ ${ }^{b}$ Instituto Nacional del Carbon (CSIC), 33080 Oviedo, Spain
}

\begin{abstract}
Previous experimental results have shown that a system with molten carbonate and solid oxide electrolyte is feasible for Direct Carbon Fuel Cell (DCFC). A study is presented to investigate cell performance with a range of solid carbon (i.e. coals, biochars, graphite) and operation mode in this hybrid electrolyte system. The results show that less crystalline coal with high fixed carbon, low sulfur, medium volatile material and moisture is best suited to this system. Using high rank of fuel such as anthracite coal, good cell performance can be obtained only by elevating temperature and with adequate pretreatment to remove impurities. Discussion of cell operation indicates that cell degradation and operation failure were due to coal agglomeration, ash buildup, and limited fuel supply in potentiostatic mode. Instead, galvanostatic operation gave stable cell performance over 60 hours. This result allows better understanding of anode reaction mechanism on the hybrid electrolyte system. Thus, long-term operation is promised when suitable solid fuel and optimized operation parameters are applied.

(C) 2014 The Electrochemical Society. [DOI: 10.1149/2.025405jes] All rights reserved.
\end{abstract}

Manuscript submitted January 16, 2014; revised manuscript received March 3, 2014. Published March 11, 2014.

Direct Carbon Fuel Cell (DCFC) is a promising technology to use solid carbon for energy production. This technology allows direct conversion of chemical energy to electricity, thus giving a high thermodynamic efficiency, i.e. $100 \%$, when carbon is oxidized to carbon dioxide. The concept of DCFC is simple. Solid carbon is fed to a fuel cell and electrochemically oxidized at the anode to produce electricity. ${ }^{1-3}$ Pure product, carbon dioxide $\left(\mathrm{CO}_{2}\right)$, is obtained in complete oxidation and is easy for carbon sequestration. Furthermore, application of DCFC benefits from sufficient fuel supply with abundant coal and biomass in the world. These advantages as well as established infrastructure of transportation, storage, and processing for solid carbon make a DCFC feasible and very attractive.

One of design challenges to develop a DCFC is choice of fuel. ${ }^{4}$ Despite large reserves of solid carbon available, different sources of carbon have varying activity and indeed affect DCFC performance. In the past, many attempts have been made to evaluate effect of solid carbon on DCFC for electric power generation. Cooper et al. ${ }^{5}$ reported cell polarization on nine particulate carbon derived from fuel oil, coal, biochar, petroleum coke, etc. The highest discharge rate, $100-125 \mathrm{~mA}$ $\mathrm{cm}^{-2}$ at $0.8 \mathrm{~V}$ and $800^{\circ} \mathrm{C}$, was obtained with biochar-derived carbon. They found that properties of carbon fuel which control discharging rates are (i) crystallographic disorder, (ii) electrical conductivity, (iii) active surface sites, and (iv) sulfur and ash impurities. Less graphitized and high disordered carbon such as chars is more reactive to oxidation; however, this property counterbalances electrical conductivity since chars are poor conductors. By contrast, neither particle size, surface area, nor morphology was found to have much impact on the electrochemical discharge rate. Moreover, Zhu et $\mathrm{al}^{6}$ investigated factors that determine performance of carbon fuel in the DCFC with activated carbon, carbon black, and graphitic carbon. The desirable carbon fuel was chosen with small particle size, high mesoporous surface area and rich oxygen-containing surface groups. To increase oxygen function groups, coal was modified. The best performance was obtained by acid treatment rather than air oxidation or heat pyrolysis. ${ }^{7}$ In addition, Cao et al. ${ }^{8}$ published that non-oxidant acids (HF) treatment is more effective than oxidant acid $\left(\mathrm{HNO}_{3}\right)$ and base $(\mathrm{NaOH})$ treatment. They combined acid treatment and presoaking of carbon with $\mathrm{Li}_{2} \mathrm{CO}_{3} / \mathrm{K}_{2} \mathrm{CO}_{3}$, thus shifting onset potential around $100 \mathrm{mV}$ and current density of $50 \mathrm{~mA} \mathrm{~cm}^{-2}$.

Recently, carbon configuration (rigid, particle bed, slurry) and its morphology (dense to porous; ordered to highly disordered) on DCFC efficiency and polarization were also analyzed. ${ }^{9}$ Nearly all polarization curves are found to involve two distinct segments at low and high current densities, respectively. This break-up is attributed to carbon

*Electrochemical Society Active Member.

${ }^{\mathrm{z}}$ E-mail: jtsi@st-andrews.ac.uk properties such as particle size, packing density, degree of crystallinity, wetting behavior, and operating temperature. The analysis concludes that activation polarization is the controlling factor at low current densities due to blockage of oxide adsorption sites by increased $\mathrm{CO}_{2}$, while ohmic activation and mass transfer are important at high current densities..$^{10}$ Apart from the coal rank properties, extrinsic composition in coal such as mineral contents also affects the DCFC performance. Impurities such as $\mathrm{Al}_{2} \mathrm{O}_{3}$ and $\mathrm{SiO}_{2}$ are inhibit the anodic reaction, whereas $\mathrm{CaO}, \mathrm{MgO}$ and $\mathrm{Fe}_{2} \mathrm{O}_{3}$ are catalytically beneficial on the electrochemical oxidation of carbon. ${ }^{7}$

Although previous literature has provided valuable information investigating type of carbon on DCFC performance, the system of focus was Molten Carbonate Fuel Cell (MCFC). Studies on influence of carbon properties in Solid Oxide Fuel Cell (SOFC) are scarce. ${ }^{11-13}$ This could be due to difficulty in direct oxidation of solid carbon in SOFCs. Nevertheless, recent work indicates that amorphous carbon is electrochemically more active than graphitic carbon. ${ }^{14-16} \mathrm{M}$. Rzeka and U. Stimming et al. ${ }^{17}$ correlated activation barriers of graphite $\left(256 \mathrm{~kJ} \mathrm{~mol}^{-1}\right)$ and amorphous carbon $\left(95-140 \mathrm{~kJ} \mathrm{~mol}^{-1}\right)$ to reverse Boudouard reaction with DCFC performance. Low cell performance shown in graphitic carbon is attributed to scission of carbon bonds, which is thought of the most important reaction step for electrooxidation of carbon. Besides, A. Kulkarni et al. ${ }^{18}$ tested graphite and amorphous carbon in the same condition. They indicated that graphite shows lower performance in spite of its good thermal oxidation stability and electricity conductivity. This is probably true since the effect of both chemical and electrochemical activity is more significant as compared to conductivity in a solid-state based DCFC.

Previous research in our group has worked on developing Hybrid Direct Carbon Fuel Cell (HDCFC). ${ }^{1922}$ The HDCFC has a hybridstate (molten and solid) electrode/ electrolyte design, which combines advantage of SOFC and MCFC. We have demonstrated the feasibility of HDCFC on bottom cells that increase cell performance by mediation of molten salts and improved contact above solid electrolyte. Here, we study the effect of carbon property on HDCFC performance with different kinds of carbon, graphite, activated carbon, pine charcoal, anthracite and bituminous coal before and after demineralization. The effect of operation mode is also investigated and discussed in the pursuit of continuous power generation.

\section{Experimental}

Cell fabrication and composition.- An anode-supported fuel cell was used in this study. The cell consists of an anode support, an anode interlayer, an electrolyte, a cathode interlayer and a cathode. The anode support and anode interlayer were prepared by tape casting with slurries containing nickel oxide (NiO; Novamet) and $13 \mathrm{~mol} \%$ 


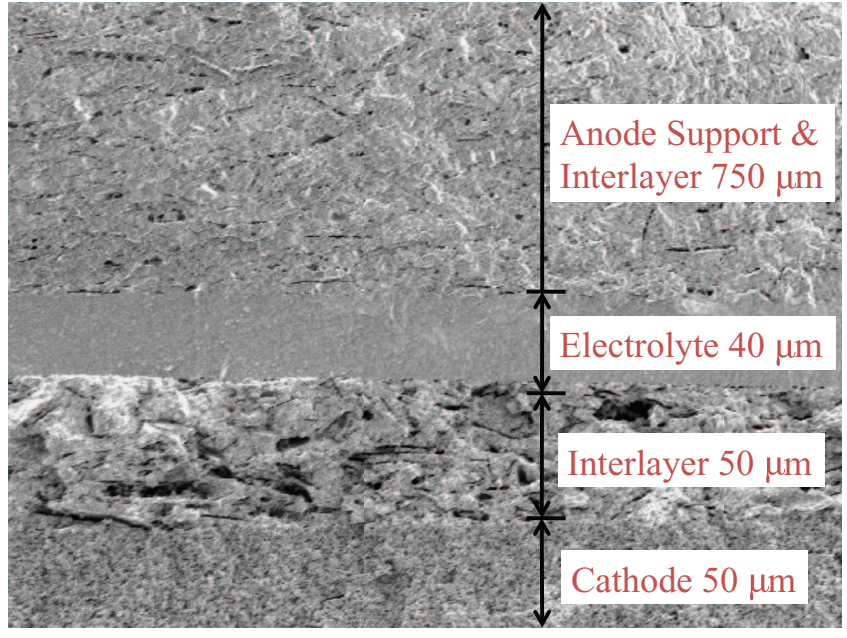

Figure 1. Scanning electron microscopy (SEM) image of an anode-supported cell.

yttrium stabilized zirconia (13YSZ, United Ceramics) with adequate amount of binder, dispersant, and pore former. The composition of $\mathrm{NiO} / 13 \mathrm{YSZ}$ in anode support and anode interlayer are 60/40 and $50 / 50$ by weight, respectively. The electrolyte was $8 \mathrm{~mol} \%$ YSZ (PIKEM) and prepared by tape casting. The tapes of anode support, anode interlayer and electrolyte were then dried at room temperature after casting, laminated, and sintered at $1673 \mathrm{~K}$ for $4 \mathrm{~h}$ to produce a half-cell. To form a cathode interlayer and cathode, the half-cell was painted with lanthanum strontium manganite/YSZ (LSM/YSZ, $50 / 50$ by weight) and a pure LSM on the electrolyte side and further calcined at $1373 \mathrm{~K}$ for $2 \mathrm{~h}$. The final cell was circular with a diameter of $25 \mathrm{~mm}$. The morphology and dimension of different layers in the cell is shown in Figure 1.

Solid fuel and characterization.- Solid fuels used in this study include two mineral coals of different rank, bituminous and anthracite coal from Spanish basins, a pine charcoal (supplied by INCAR-CSIC, Spain), carbon black (XC-72R, Cabot), and graphite (Fisher). The two coals and the pine charcoal were dry-milled in a bench mortar mill and sieved under 75 microns. The raw coals (B-I-M and A-II-M) were further subjected to a demineralization process by treating with acids. The process consists of i) mixing $30 \mathrm{~g}$ coal with $100 \mathrm{~mL}$ of hydrochloric acid $(36 \% \mathrm{HCl})$ and $150 \mathrm{~mL}$ distilled water in a Teflon beaker, ii) stirring the mixture at $75^{\circ} \mathrm{C}$ for $45 \mathrm{~min}$, followed by filtering and washing with distilled water three times, iii) washing with acid as in step i - ii by $200 \mathrm{~mL}$ hydrofluoric acid (HF), iv) repeating $\mathrm{HCl}$ acid treatment as in step i-ii, and vi) filtering and washing resultant sample with distilled water until neutral $\mathrm{pH}$. The final acid-demineralized sample was obtained after drying at $110^{\circ} \mathrm{C}$ overnight. Table I shows the composition of all raw coals and the acid-demineralized one. Compared with the raw coals, the acid-demineralized one contains very low mineral matters, i.e. $1.6 \mathrm{wt} \%$ in the case of A-II-M and $0.4 \mathrm{wt} \%$ for B-I-M. On the other hand, mineral content in the pine charcoal is low about $1.6 \mathrm{wt} \%$ because of biomass nature; whereas, the charcoal contains high volatile matters (i.e. $32.4 \mathrm{wt} \%$ ) even after pyrolysis in an inert atmosphere at ca. $400^{\circ} \mathrm{C}$.

The standard used for analysis of chemical composition in coal are listed in the following: ASTM D-5373 for C, $\mathrm{H}$ and $\mathrm{N}$ by a LECO CHN 2000, ASTM D-4239 for oxygen and sulfur in a LECO TRUSPEC Micro-O and LECO S632, respectively, ASTM 7582 for moisture and ash, ISO562 for volatile matter, ISO1928 for calorific value. Ash composition of the raw coals was also analyzed with aid of X-ray fluorescence in a Bruker SRS 3000. Distribution of particle size was checked by coulter analysis (LS13320, Beckman, with the ALM water module). The size of coal particle all lies within 50 microns with a bimodal particle size distribution profile, showing a maximum and a shoulder at 33-36 and 15-17 microns, respectively. Crystalline structures of carbon was determined by a Stoe Stadi X-ray diffractometer from 10 to $90^{\circ}$ in a step size $0.02^{\circ}(2 \theta)$ with $\mathrm{Cu} \mathrm{K} \alpha$ radiation.

Cell testing and performance evaluation.- Cell performance was evaluated with a single cell that was mounted onto one end of an alumina tube (OD: $25 \mathrm{~mm}$; ID: $20 \mathrm{~mm}$ ). The tube serves as an anode chamber to contain solid fuel and carbonates, $\mathrm{Li}_{2} \mathrm{CO}_{3}$ (Aldrich) $/ \mathrm{K}_{2} \mathrm{CO}_{3}$ (Fisher) $(62 / 38 \mathrm{~mol} \%$ ). Solid fuel and carbonates were first mixed before being placed on the anode inside the tube. The mixture has a weight ratio of 4 to 1 for carbon to carbonates. Current collection was built at the anode and cathode with silver adhesive (Heraeus) attached by a silver wire to a potentiostat (Solartron $1280 \mathrm{~B}$ ). The area of silver adhesive on the cathode $\sim 1 \mathrm{~cm}^{2}$ was used as active area for performance normalization. Prior to cell testing, assembly of the cell, current collector, and alumina tube was heated to testing temperatures, i.e. $700-800^{\circ} \mathrm{C}$, in a furnace. The fuel cell was operated in a battery mode without gas flow on the anode (top end of alumina tube was capped) and the cathode was exposed to ambient air. Cell performance such as open circuit voltage (OCV) and voltage-current density characteristics ( $V$ - $i$ curves) were measured. Long-term cell performance was evaluated by operating a HDCFC under a potentiostatic or galvanostatic mode for a specific period of time.

\section{Results and Discussion}

HDCFC performances and XRD pattern of carbon fuels. - Figure 2 presents power density vs. time profiles $(P-t)$ of a HDCFC with graphite, anthracite, bituminous coal, and pine charcoal, together with their X-ray diffraction (XRD) patterns. The $P$ - $t$ profiles and XRD patterns show that electric power generation and long-term stability have strong correlation with crystalline structure of solid carbon. A

Table I. Proximate and ultimate composition analysis of coal fuel.

\begin{tabular}{|c|c|c|c|c|c|c|c|c|c|}
\hline \multirow[b]{2}{*}{ Carbon Type } & \multicolumn{4}{|c|}{ Ultimate Analysis } & \multicolumn{4}{|c|}{ Proximate Analysis } & \multirow[b]{2}{*}{$\begin{array}{r}\Delta \mathrm{H}^{\mathrm{b}} \\
\mathrm{kcal} / \mathrm{kg}\end{array}$} \\
\hline & $\begin{array}{l}\mathrm{C} \\
(\%)\end{array}$ & $\begin{array}{c}\mathrm{H} \\
(\%)\end{array}$ & $\begin{array}{c}\mathrm{O} \\
(\%)\end{array}$ & $\underset{(\%)}{S}$ & $\begin{array}{l}\mathrm{FC}^{\mathrm{a}} \\
(\%)\end{array}$ & $\begin{array}{l}\mathrm{VM} \\
(\%)\end{array}$ & $\begin{array}{l}\text { Ash } \\
(\%)\end{array}$ & $\begin{array}{l}\text { Moisture } \\
\quad(\%)\end{array}$ & \\
\hline Anthracite coal milled (A-II-M) & 88.6 & 4 & 3.7 & 2.2 & 56.3 & 9.7 & 32.5 & 1.5 & 5431 \\
\hline $\begin{array}{l}\text { Anthracite coal milled and demineralized } \\
\text { (A-II-MD) }\end{array}$ & 90.8 & 3.5 & 2.8 & 1.4 & 87.6 & 10.8 & 1.6 & 1.5 & 8093 \\
\hline Bituminous coal milled (B-I-M) & 89.6 & 4.6 & 3.5 & 0.7 & 76.7 & 18.4 & 4.1 & 0.8 & 8175 \\
\hline $\begin{array}{l}\text { Bituminous coal milled and demineralized } \\
\text { (B-I-MD) }\end{array}$ & 89.9 & 4.3 & 3.5 & 0.7 & 81.5 & 18.1 & 0.4 & 1.2 & 8252 \\
\hline Pine charcoal & 75.6 & 3.9 & 21 & 0.0 & 66 & 32.4 & 1.6 & 5.5 & 6745 \\
\hline
\end{tabular}


(a)

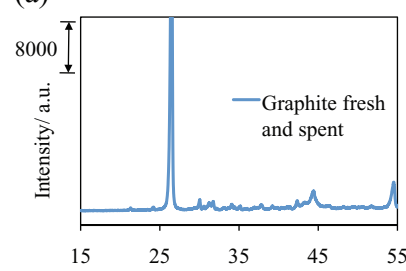

(c)

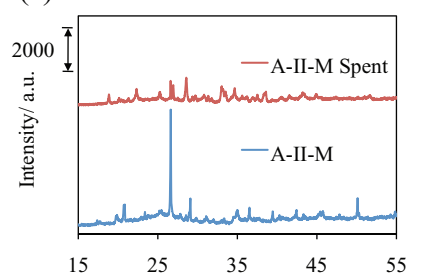

(e)

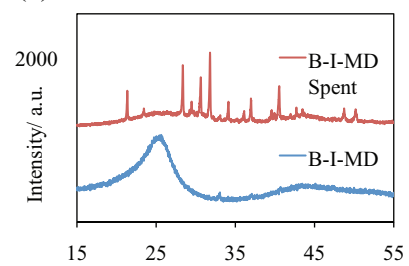

(g)

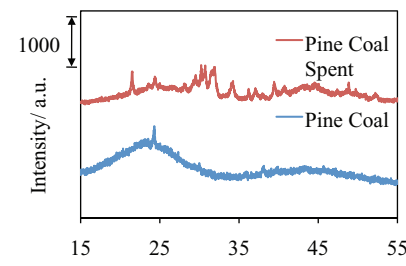

(b)

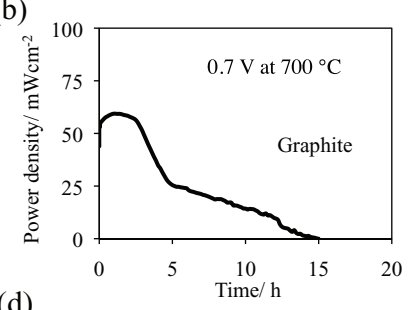

(d)

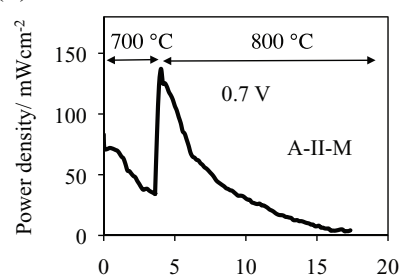

(f)

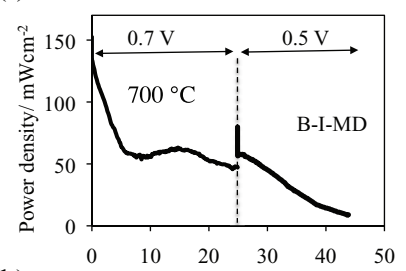

(h)

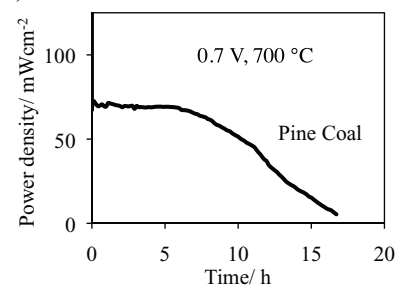

Figure 2. Power density versus time of a HDCFC on different carbon and the corresponding X-ray diffraction pattern of solid fuel.

high power density and good stability were obtained in the HDCFC using less crystalline carbon, which is characterized with a broad peak at $2 \theta=20-30^{\circ}$ on the XRD pattern. The XRD peak at $2 \theta$ $=20-30^{\circ}$ has been ascribed to (002) reflection for graphite and resulted from stacking structure of aromatic layers. ${ }^{6,23}$ The interlayer spacing of the stack structure, $d_{002}$, can be calculated from Bragg's equation:

$$
n \lambda=2 d \sin \theta
$$

The $d_{002}$ for graphite, anthracite, bituminous coal and pine charcoal were calculated to be $0.334,0.335,0.355$, and $0.368(\mathrm{~nm})$, respectively. These values as well as the sharpness of (002) peak in Fig. 2 indicate that the degree of graphitization follows in the order of graphite $>$ anthracite $>$ bituminous $>$ pine charcoal. The result indicated that high rank of coal has higher perfection of periodicity in the stacking structure toward graphitization, i.e. low concentration of edge atoms compared to those in the basal plane, thereby leading to lack of active sites and low activity for reaction. Elevating temperature improved the cell performance on high graphitized coal as shown in Fig. 2d. This improvement was attributed to both enhanced kinetics and thermodynamics. High temperature increases ionic conductivity of fuel cell, thereby having more oxygen diffusing toward anode for reaction. In addition, rate of chemical reaction is doubled by $10^{\circ} \mathrm{C}$ increase. Thus, oxidation of carbon can be enhanced at higher temperatures since activity of graphite was low, seen from Fig. 2 b. Nevertheless, non-pretreated anthracite coal in Fig. 2d contains too many impurities (32 wt\% ash in Table I); the power density decayed with ash buildup as examined after the run (images shown below). On the other hand, the cell performance could be affected also by composition and properties such as surface area due to agglomeration during testing; these are further discussed in next section.

Effect of carbon type on HDCFC performance.- Table II summarizes the cell performance of initial and end activity for all tested carbon. Voltage-current characteristics (V-I curves) corresponding to different carbons in Fig. 2 are presented in Figure 3. The cell performance gave a best activity with an initial current density of $326 \mathrm{~mA}$ $\mathrm{cm}^{-2}$ and power density of $165 \mathrm{~mW} \mathrm{~cm}{ }^{-2}$ at $700^{\circ} \mathrm{C}$ on demineralized bituminous coal. This cell continued to run for total $47 \mathrm{~h}$ under polarization at $0.7 \mathrm{~V}$ for $25 \mathrm{~h}$ and then at $0.5 \mathrm{~V}$ for $22 \mathrm{~h}$. It was stopped with end activity of $23.3 \mathrm{~mA} \mathrm{~cm}^{-2}$ and $11.7 \mathrm{~mW} \mathrm{~cm}^{-2}$. The end activity, as shown in Table II, was very subject to type of carbon as well as time of run (probably change of composition during operation). By contrast, the initial activity showed that less crystalline carbon gives higher activity. Considering initial anode reaction, the open circuit voltage $(\mathrm{OCV})$ for all coal was close to $1.02 \mathrm{~V}$, a theoretical value of carbon oxidation:

$$
\mathrm{C}+\mathrm{O}_{2} \rightarrow \mathrm{CO}_{2}
$$

The ideal OCV indicated that coal has a fairly good initial activity toward oxidation. On the contrary, the cell with graphite had a lower $\mathrm{OCV}$, i.e. $0.87 \mathrm{~V}$, suggesting that its anodic oxygen activity $\left(a_{\mathrm{O} 2}\right)$ was high by Nernst equation: ${ }^{24}$

$$
E=E^{0}-\frac{R T}{n F} \ln \left(\frac{a_{O 2, c}}{a_{O 2, a}}\right)
$$

$\mathrm{a}_{\mathrm{O} 2, \mathrm{c}}$ and $\mathrm{a}_{\mathrm{O} 2 \text {, a }}$ are oxygen activity on cathode and anode, respectively.

\begin{tabular}{|c|c|c|c|c|c|c|c|}
\hline \multirow[b]{2}{*}{ Carbon Type } & \multicolumn{3}{|c|}{ Initial Activity } & \multirow[b]{2}{*}{$\begin{array}{l}\text { Time in } \\
\text { the run }(\mathrm{h})\end{array}$} & \multicolumn{3}{|c|}{ End Activity } \\
\hline & $\begin{array}{l}\text { OCV } \\
\text { (Volt) }\end{array}$ & $\begin{array}{c}\mathrm{I}_{0.5^{\mathrm{a}}} \\
\left(\mathrm{mAcm}^{2}\right)\end{array}$ & $\begin{array}{c}\mathrm{P}_{0.5}{ }^{\mathrm{a}} \\
\left(\mathrm{mWCm} \mathrm{cm}^{-2}\right)\end{array}$ & & $\begin{array}{l}\text { OCV } \\
\text { (Volt) }\end{array}$ & $\underset{\left(\mathrm{mAcm}{ }^{2}\right)}{\mathrm{I}_{0.5} \mathrm{a}^{\mathrm{a}}}$ & $\begin{array}{c}\mathrm{P}_{0.5^{\mathrm{a}}} \\
\left.(\mathrm{mWcm})^{-2}\right)\end{array}$ \\
\hline Graphite & 0.87 & 133.4 & 67.1 & 15 & 0.64 & 18.5 & 9.36 \\
\hline Anthracite coal milled (A-II-M) & 0.99 & 193.1 & 96.9 & 17.4 & $0.71^{\mathrm{b}}$ & $23.7^{\mathrm{b}}$ & $12.0^{\mathrm{b}}$ \\
\hline $\begin{array}{l}\text { Anthracite coal milled and demineralized } \\
\text { (A-II-MD) }\end{array}$ & 1.01 & 204.2 & 102.5 & 37.8 & 0.75 & 40.8 & 20.4 \\
\hline Bituminous coal milled (B-I-M) & 1.00 & 230.5 & 115.3 & 40.1 & 0.94 & 55.2 & 27.6 \\
\hline $\begin{array}{l}\text { Bituminous coal milled and demineralized } \\
\text { (B-I-MD) }\end{array}$ & 1.00 & 326.5 & 165.4 & 47.2 & 0.74 & 23.3 & 11.7 \\
\hline Pine Coal & 1.00 & 190 & 95.7 & 16.7 & 0.76 & 38.3 & 19.3 \\
\hline Activated Carbon (XC-72R) & 0.93 & 292.9 & 145.3 & 27.3 & 0.79 & 92.7 & 46.2 \\
\hline
\end{tabular}
The high $a_{\mathrm{O} 2}$ implied that the oxidation of graphite on anode was slow

Table II. Summary of cell performance for all carbon fuel.

${ }^{\mathrm{a}} \mathrm{I}_{0.5}, \mathrm{P}_{0.5}$ : current and power density at voltage $=0.5 \mathrm{~V}$;

b collected at $800^{\circ} \mathrm{C}$ 
(a)

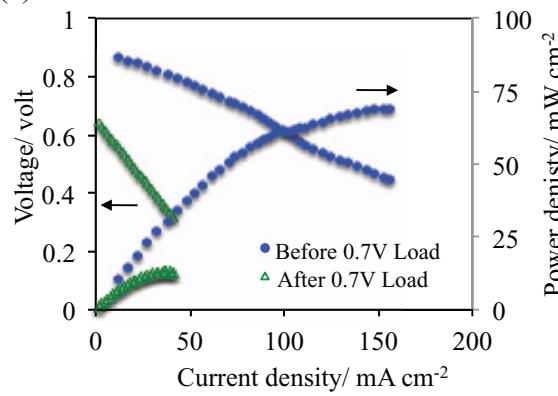

(c)

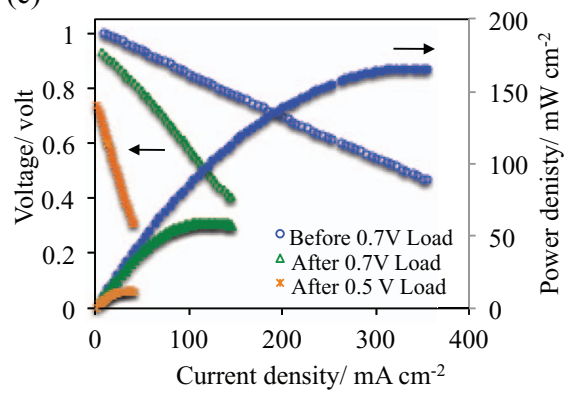

(b)

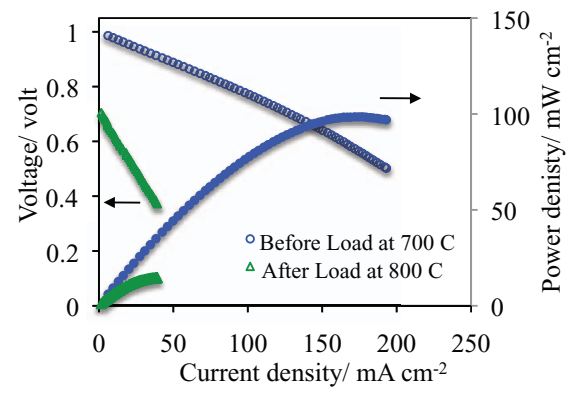

(d)

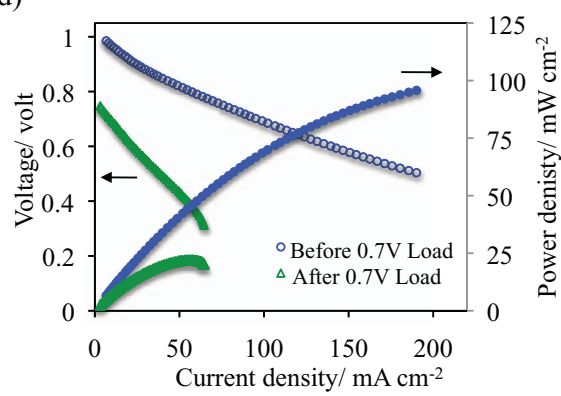

Figure 3. Voltage-current chracteristics (V-I curves) for a) graphite, b) A-II-M anthracite coal, c) B-I-MD bituminous coal, and d) pine charcoal. due to high crystallinity and low activity of carbon. Several types of coal and graphite have been tested in molten salt by fuel cell and the same result was observed. ${ }^{25}$ Hackett et al. ${ }^{26}$ claims that a high OCV for coal is attributed to high electrochemical activity while graphite is more stable for long-term operation. However, no further details of fuel composition and analysis of its effect were given.

Figure 4 plots cell performance versus composition of coal. Analysis of the result shows that good cell performance was obtained with the coal containing high fixed carbon, low sulfur, medium amount of volatile material and moisture. Higher content of fixed carbon means more chemical energy, i.e. a high calorific value, thus giving a cell better performance. ${ }^{7}$ Anthracite coal has the highest content of carbon after demineralization; on the other hand, high rank of coal has more crystalline structure, thus with a low activity. Low sulfur content is also beneficial to cell performance since sulfur is poisonous to nickel cermet anode. ${ }^{5,27}$ Pine charcoal, a biomass resource, has almost zero sulfur content, but showed poor performance. The reason of poor performance for pine charcoal was attributed to volatile ma- (a)

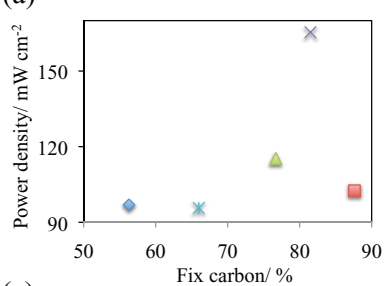

(c)

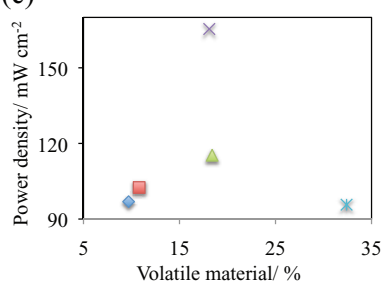

(b)

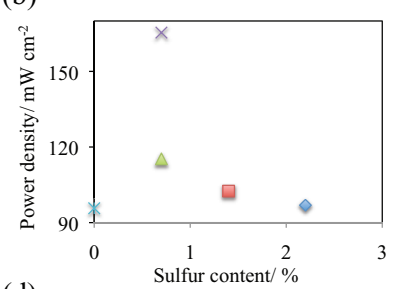

(d)

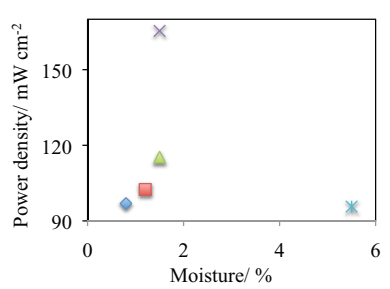

$\leadsto$ A-II-M $\approx$ A-II-MD $\leadsto$ B-I-M $*$ B-I-MD $*$ Pine

Figure 4. Relationship of initial cell performance and coal composition. terial $(32.4 \mathrm{wt} \%)$ and moisture $(5 \mathrm{wt} \%)$, which resulted in a lower calorific value as presented in Table I. Nevertheless, we noticed that the power density associated with pine charcoal remained stable in first $5 \mathrm{~h}$, compared with the decreasing performance on other carbon. Stable power density was also observed when pyrolyzed fiberboard is used as a fuel in our previous studies. ${ }^{20,21}$ This congruence was attributed to facile gasification and oxidation kinetics on biomassderived charcoal because of high pore volume and low crystallinity. Especially, gasification reaction produces reducing gases such as $\mathrm{H}_{2}$ and $\mathrm{CO}$, which stabilize cell performance in the beginning when solid electrode/ electrolyte is used. This feature is different from Molten Salt Fuel Cell, in which high fixed content of carbon is a priority for fuel requirement and very influential in cell performance. In terms of this, pine charcoal could be a potential fuel for direct carbon fuel cell on our system. One approach we suggest is to remove moisture and volatile material from pine charcoal by adequate pretreatment. In this way, the calorific value of pine charcoal could be increased as well as performance of the cell.

Long-term operation.- As discussed above, performance of the carbon fuel cell was largely affected by structure and composition of carbon fuel. Using non-demineralized anthracite and bituminous coal such as A-II-M and B-I-M, the cell degraded fast along with several inorganic residues buildup and coal agglomeration in the end of run, as shown in Figure 5. Compositions of the inorganic residues are presented in Table III. Besides these inorganic components, carbonates may decompose to oxides, which accumulate with the residues from (a)

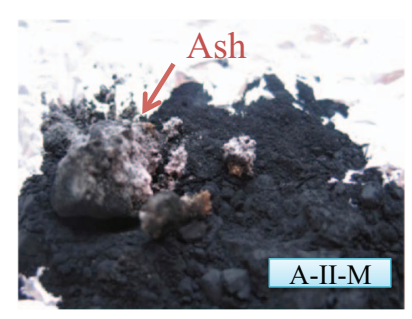

(b)

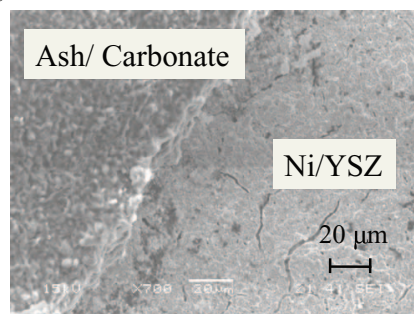

Figure 5. In the of run for anthracite (A-II-M) coal with ash buildup (a), and electrode SEM image (b). 
Table III. Compositions of ash from anthracite and bituminous coal.

Composition/\%

\begin{tabular}{lccccccccc}
\cline { 2 - 8 } Carbon Type & $\mathrm{Na} 2 \mathrm{O}$ & $\mathrm{MgO}$ & $\mathrm{A} 12 \mathrm{O} 3$ & $\mathrm{SiO} 2$ & $\mathrm{P} 2 \mathrm{O} 5$ & $\mathrm{~K} 2 \mathrm{O}$ & $\mathrm{CaO}$ & $\mathrm{TiO} 2$ & $\mathrm{Fe} 2 \mathrm{O} 3$ \\
\hline Anthracite coal milled (A-II-M) & 0.79 & 1.23 & 23.6 & 57.7 & 0.13 & 4.59 & 1.8 & 0.89 & 6.16 \\
Bituminous coal milled (B-I-M) & 1.09 & 0.93 & 28.74 & 46.2 & 2.13 & 2.2 & 2.46 & 1.74 & 9.32
\end{tabular}

coal, i.e. ash. These impurities thus form a barrier layer or simply precipitate on anode surface. The precipitation prevented solid carbon from oxidation and exposed the anode in an oxidizing environment, thereby leading to failure of continuous operation.

On the other hand, the cell degradation on demineralized coal, bituminous B-I-MD for example, was more complex. Figure 6 shows P-V-I curves and impedance spectra of a HDCFC using B-I-MD coal during the run at $700^{\circ} \mathrm{C}$. The $\mathrm{P}-\mathrm{V}-\mathrm{I}$ curves indicated that the $\mathrm{OCV}$ was still close to that of equilibrium for carbon oxidation after $25 \mathrm{~h}$ while production of current decreased. Moreover, the V-I curve at $25 \mathrm{~h}$ incurred a more negative slope at higher current density, inferring a start of diffusion-limited regime. We speculated that anodic reaction passed reaction-control regime as most active fuel was quickly consumed in the beginning and shortly arrived at a diffusion-control regime. Thereafter, carbon was deficient at interface of anode for direct oxidation. Although solid carbon can be gasified in testing conditions to produce carbon monoxide for oxidation, ${ }^{28,29}$ the activity of gasification could be insufficient to supply fuel for digestion of oxidants from cathode. The accumulation of oxidants, i.e. oxygen anion, thus oxidized nickel on the anode to nickel oxide. The redox reaction of nickel governed the anodic reaction after $47 \mathrm{~h}$, as evidenced by an $\mathrm{OCV} \sim 0.7 \mathrm{~V}^{24,30}$ This was also confirmed by end OCVs in Table II and Fig. 3 for other coals. Furthermore, Fig. $6 \mathrm{~b}$ provides information of electrode resistance, both ohmic and non-ohmic, increased during the run. The oxidation of nickel could be the reason to increase ohmic resistance since the oxide has poor conductivity. Besides, the impedance spectra in the end of run shows a high polarization arc, suggesting that diffusion of fuel was difficult and fuel was hardly accessed by oxidants at interface of electrode and current collector.
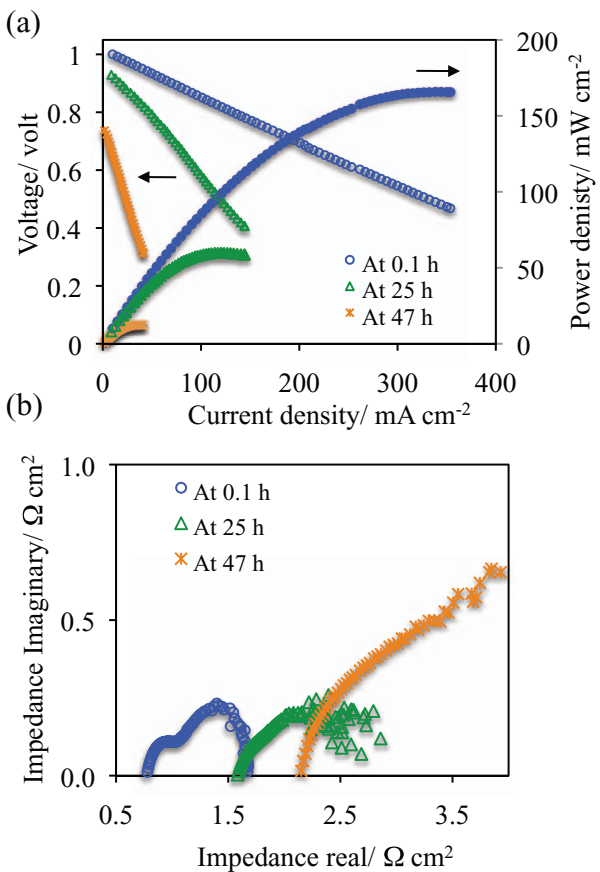

Figure 6. (a) P-V-I curves and (b) electrochemial impdance spectra of a HDCFC with B-I-MD coal ( $8 \mathrm{~g}$ carbon fuel and $2 \mathrm{~g}$ carbonate mixture) during potentiostatic operation at $700^{\circ} \mathrm{C}(0.7 \mathrm{~V}$ in $0-25 \mathrm{~h}$ and $0.5 \mathrm{~V}$ in $25-47 \mathrm{~h})$.
Another key factor to build a DCFC is long-term operation. The information in the literature regarding long-term testing is limited regardless of molten carbonate or solid oxide electrolyte based DCFC. The difficulty of operating a cell for long time could be probably due to insufficient understanding of electrode reaction mechanism, issue of contact, ${ }^{31}$ current collection and continuous feeding. However, mode of operation, galvanostatic or potentiostatic, is often neglected. Galvanostatic mode monitors voltage change by operating a cell under a constant current; whereas, potentiostatic mode measures current production at a fixed electric load. An ideal current density in the potentiostatic mode (or voltage in galvanostatic mode) can be calculated by ohm's law $(I=V / R)$ and maintain if fuel is constantly supplied. In practice, the current density depends on rate of carbon oxidation, which could be under reaction or diffusion control. Thus, the current or cell performance decreases when the rate of oxidation is limited. This limiting regime seems to be affected by different mode of operation to some extent and needs more investigation.

In the present study, long-term performance was mostly evaluated by maintaining a cell at certain voltage under a potentiostatic mode. The potentiostatic operation provides the advantage that overpotential of a fuel cell can be altered for high efficiency of voltage, e.g. 70\% if $0.7 \mathrm{~V}$ is chosen relative to an $\mathrm{OCV}$ of $1.02 \mathrm{~V}$ for carbon oxidation. Nevertheless, the cell operation fails when the voltage of a cell could not sustain above the redox potential of nickel anode, i.e. $\sim 0.7 \mathrm{~V}$ at $700^{\circ} \mathrm{C}$, due to insufficient fuel supply. In terms of this, galvanostatic operation was adopted in some cases for investigation.

Figure 7 presents two examples of a HDCFC operated first in a potentiostatic mode, followed by a galvanostatic mode. Fig. 7a shows that a HDCFC started to degrade after $5 \mathrm{~h}$ under $0.7 \mathrm{~V}$; thereafter, a power density of $\sim 50 \mathrm{~mW} \mathrm{~cm} \mathrm{~cm}^{-2}$ was kept when a 0.1 A current was drawn from the cell. The voltage corresponding to $0.1 \mathrm{~A}$ was

(a)

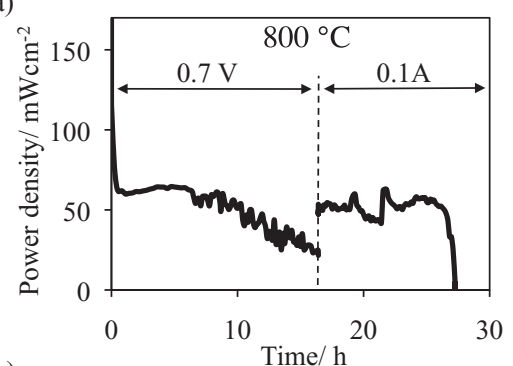

(b)

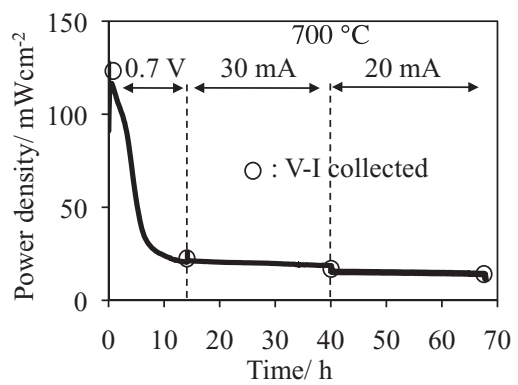

Figure 7. Power density versus time of a HDCFC with (a) $4 \mathrm{~g}$ activated carbon (XC-72R) and (b) $8 \mathrm{~g}$ non-demineralized bituminous coal (B-I-M) as fuel (note: the ratio of carbon to carbonate were 4 to 1 ). 
$\sim 0.5 \mathrm{~V}$. This voltage lies below redox potential of nickel and could be maintained if equilibrium of nickel and nickel oxide exists during operation. The equilibrium lost, as nickel oxide could not be reduced back to nickel because fuel is consumed, thus resulting in a sharp drop of cell performance. Cooper et. al. ${ }^{5}$ also observed a sharp drop of voltage after $32 \mathrm{~h}$ operating a cell at constant current density, $27 \mathrm{~mA} \mathrm{~cm}{ }^{-2}$. However, whether this is a characteristic of fuel consumption in galvanostatic operation was not discussed (note: they stated in the abstract that the voltage fell off due to fuel consumption). Lee et. al. ${ }^{32}$ reported that the voltage of a MCFC decreased with time to zero in $25 \mathrm{~h}$ at a constant current density using bamboo-derived activated carbon as fuel. On the contrary, carbon fuel was still available since the corresponding carbon amount for current generation was much less than that initially loaded. These phenomena could have relation with mechanism of cell failure and still remain unclear.

Fig. 7b shows a HDCFC with non-demineralized bituminous coal for long-term operation of nearly $70 \mathrm{~h}$. This cell was operated at constant $0.7 \mathrm{~V}$ for $13 \mathrm{~h}$ and then at constant current, $30 \mathrm{~mA}$ and $20 \mathrm{~mA}$ for $27 \mathrm{~h}$ and $28 \mathrm{~h}$, respectively. The OCVs were recorded to $1.02 \mathrm{~V}$ at $\mathrm{t}=0 \mathrm{~h}, 0.95 \mathrm{~V}$ at $\mathrm{t}=13 \mathrm{~h}$, and $0.97 \mathrm{~V}$ at $\mathrm{t}=40 \mathrm{~h}$. The high OCV in first $40 \mathrm{~h}$ implied that the anode reaction was still in equilibrium with carbon oxidation. The decrease of power generation should be resulted from ash buildup and coal agglomeration rather than potentiostatic operation. Similar to non-demineralized anthracite coal, this bituminous coal contains low fixed carbon and high content of ash; therefore, the degradation of carbon was fast and the oxidation became difficult. In spite of this, Fig. 7b illustrated a steady power generation in a galvanostatic mode. This result indicated that operation of a HDCFC by drawing a current could not only better fit in our design for long-term testing but also provide a high efficiency at affordable high OCVs.

\section{Conclusions}

This study investigated the cell performance on a range of coals and effect of operation mode in a hybrid direct carbon fuel cell (HDCFC). Graphite, activated carbon, anthracite, bituminous coal, and pine charcoal were used as solid fuel for power generation. The correlation of power generation and X-ray diffraction pattern of carbon indicated that a high power density and good stability were obtained in the HDCFC using less crystalline carbon, as characterized with a broad peak at $2 \theta=20-30^{\circ}$ on the XRD pattern. High rank of coal has high crystalline nature such as graphite, thus exhibiting less active sites and low activity. Besides, the analysis of coal composition shows that good cell performance was obtained with the coal containing high fixed carbon, low sulfur, medium amount of volatile material and moisture. Pine charcoal, a biomass resource, has almost zero sulfur content and can be a potential fuel after adequate pretreatment to remove moisture and volatile material.

The result and discussion of long-term operation concluded that i) fast cell degradation was due to coal agglomeration and ash buildup such as on non-demineralized coal, ii) cell operation failed because the voltage could not sustain high in a potentiostatic mode due to difficult fuel diffusion, thus causing oxidation of nickel anode, iii) galvanostatic operation with a current that allows a high OCV could not only provide a high efficiency but also better fit in our design for continuous electric power generation.

\section{Acknowledgments}

The authors thank for the financial support from European Coal and Steel Community, and also to the Royal Society for a Wolfson Merit Award. The authors also give many thanks to Jim Rennie for building cell-testing set-up.

\section{References}

1. D. Cao, Y. Sun, and G. Wang, J. Power Sources, 167, 250 (2007)

2. S. Giddey, S. P. S. Badwal, A. Kulkarni, and C. Munnings, PROG ENERG COMBUST, 38, 360 (2012).

3. T. M. Gür, J Electrochem Soc, 157, B751 (2010).

4. A. C. Rady, S. Giddey, S. P. S. Badwal, B. P. Ladewig, and S. Bhattacharya, Energy Fuels, 26, 1471 (2012)

5. N. J. Cherepy, R. Krueger, K. J. Fiet, A. F. Jankowski, and J. F. Cooper, J Electrochem Soc, 152, A80 (2005).

6. X. Li, Z. Zhu, R. De Marco, A. Dicks, J. Bradley, S. Liu, and G. O. Lu, Ind. Eng. Chem. Res., 47, 9670 (2008).

7. X. Li, Z. Zhu, R. De Marco, J. Bradley, and A. Dicks, J Power Sources, 195, 4051 (2010).

8. D. Cao, G. Wang, C. Wang, J. Wang, and T. Lu, Int. J. Hydrogen Energy, 35, 1778 (2010).

9. J. F. Cooper and J. R. Selman, Int. J. Hydrogen Energy, 37, 19319 (2012)

10. H. Li, Q. Liu, and Y. Li, Electrochim. Acta, 55, 1958 (2010).

11. Y. Zhao, C. Xia, L. Jia, Z. Wang, H. Li, J. Yu, and Y. Li, Int. J. Hydrogen Energy, 38, 16498 (2013).

12. J. Yu, B. Yu, and Y. Li, Int. J. Hydrogen Energy, 38, 16615 (2013).

13. L. Jia, Y. Tian, Q. Liu, C. Xia, J. Yua, Z. Wang, Y. Zhao, and Y. Li, J Power Sources, 195, 5581 (2010).

14. A. Elleuch, A. Boussetta, J. Yu, K. Halouani, and Y. Li, Int. J. Hydrogen Energy, 38 $16590(2013)$.

15. A. Elleuch, J. Yu, A. Boussetta, K. Halouani, and Y. Li, Int. J. Hydrogen Energy, 38, 8514 (2013).

16. A. Elleuch, A. Boussetta, K. Halouani, and Y. Li, Int. J. Hydrogen Energy, 38, 16605 (2013).

17. S. Nürnberger, R. Bußar, P. Desclaux, B. Franke, M. Rzepka, and U. Stimming, Energy Environ. Sci., 3, 150 (2010).

18. A. Kulkarni, S. Giddey, and S. P. S. Badwal, Solid State Ionics, 194, 46 (2011).

19. K. Pointon, B. Lakeman, J. T. S. Irvine, J. Bradley, and S. Jain, J. Power Sources, 162, 750 (2006)

20. Y. Nabae, K. D. Pointon, and J. T. S. Irvine, Energy Environ. Sci., 1, 148 (2008).

21. C. Jiang, J. Ma, A. D. Bonaccorso, and J. T. S. Irvine, Energy Environ. Sci., 5, 6973 (2012).

22. A. C. Chien, G. Corre, R. Antunes, and J. T. S. Irvine, Int. J. Hydrogen Energy, 38, 8497 (2013).

23. H. Takagia, K. Maruyama, N. Yoshizawa, Y. Yamada, and Y. Sato, Fuel, 83, 2427 (2004).

24. A. C. Chien and J. T. S. Irvine, Hybrid molten carbonate /solid oxide direct carbon fuel cells, Molten Salt Chemistry, Chapter 19, p. 403-414, Elsevier 2013.

25. R. D. Weaver, S. C. Leach, A. E., and L. Nanis, SRI, Menlo Park, CA, 1979

26. G. A. Hackett, J. W. Zondlo, and R. Svensson, J Power Sources, 168, 111 (2007).

27. Z. Cheng, S. Zha, and M. Liu, J Power Sources, 172, 688 (2007).

28. A. C. Chien, T. Siengchum, and S. S. C. Chuang, ECS Trans, 33, 75 (2011)

29. A. C. Chien and S. S. C. Chuang, J. Power Sources, 196, 4719 (2011).

30. A. C. Lee, S. Li, R. E. Mitchell, and T. M. Gür, Electrochem. Solid-State Lett., 11, B20 (2008)

31. C.-C. Chen, T. Maruyam, P.-H. Hsieh, and J. R. Selman, J. Electrochem. Soc., 159 D597 (2012).

32. C.-G. Lee, H. Hur, and M.-B. Song, J Electrochem Soc, 158, B410 (2011). 